\title{
Sny i nauka
}

Artykułpowstał w ramach grantu NCN 2014/13/

Artur Hellich

Wpływ marzenia na twórczość artystyczną wszelkich typów, a w niektórych wypadkach także na twórczość naukową, nie da się zaprzeczyć.

(Leon Chwistek, 1921)

\section{Po drugiej stronie kontinuum}

Pomysł na ten artykuł zrodził się po lekturze blurba zamieszczonego na skrzydełku okładki książki Elizy Kąckiej po drugiej stronie siebie (2019). Wydawca napisał, że w utworze tym „po większej części” zapisane zostały

autentyczne sny z czasu, gdy jawę autorki - tak się złożyło - okupowała inna, aż nazbyt realnie pisana książka: Lektura jako spotkanie. Brzozowski - tekst - metoda (2017). To przed nią, jak zobaczycie, jej nocne ja daremnie umyka na drugą stronę siebie. Lecz i po drugiej stronie siebie nie sposób uciec od siebie. ${ }^{1}$

1 E. Kącka po drugiej stronie siebie, Lokator, Kraków 2019. Od tej pory odwołania do tego utworu będę zaznaczał w tekście głównym przez podanie numeru strony $w$ nawiasie.
Artur Hellich - dr, adiunkt w Instytucie Literatury Polskiej na Uniwersytecie Warszawskim, autor książki Gry z autobiografią: przemilczenia, intelektualizacje, parodie (2018). Interesuje się teorią autobiografii, dziejami polskiego literaturoznawstwa teoretycznego w XX wieku oraz pograniczami dyskursu naukowego, literackiego i autobiograficznego. Kontakt: artur.hellich@gmail.com 
Przywołana „nazbyt realnie pisana książka”, jak łatwo się domyślić, jest rozprawą naukową (książką doktorską) Kąckiej, literaturoznawczyni pracującej na Uniwersytecie Warszawskim, a także krytyczki literackiej i autorki zbioru nietypowych bajek o królewnach Elizje (2017). Równie nietypowe są zapisane w utworze po drugiej stronie siebie sny z niełatwego okresu obrony doktoratu i następujących po niej zmagań z przygotowywaniem monografii do druku. Tym właśnie dwóm książkom - dziennikowi snów i rozprawie naukowej chciałbym się przyjrzeć jako świadectwom przenikania się pracy intelektualnej i snów jej dotyczących.

Już na wstępie zaznaczam, że przypadek Kąckiej może stanowić ilustrację ogólniejszej problematyki związanej z uprawianiem kulturowej historii nauki. Żeby to uzasadnić, odwołam się do „współczesnej teorii śnienia”, doprecyzowywanej latami przez amerykańskiego psychiatrę, psychoanalityka i jednego z ważniejszych współczesnych przedstawicieli dream studies Ernesta Hartmanna. Koncepcja ta była niedawno prezentowana polskiemu czytelnikowi², nie będę więc jej obszernie referował, ograniczę się jedynie do przypomnienia kilku najistotniejszych dla mnie spostrzeżeń.

Wedle jednej z głównych tez Hartmanna, o snach warto myśleć jako jednej ze składowych kontinuum przebiegającego „od zorientowanego na cel myślenia w stanie czuwania, poprzez luźniejsze myśli albo marzenia, do fantazji, snów na jawie i ostatecznie snów"3. Wynika z tego niewątpliwie, że śnienie nie jest zupełnie niezależne od ,ja”, stanowi natomiast, ,jedną z form umysłowego funkcjonowania"4. Oczywiście w przeciwieństwie do myślenia w stanie czuwania - sprowadzającego się do odbierania bodźców zewnętrznych, kreowania spostrzeżeń, wykorzystywania słów, liczb i symboli matematycznych - śnienie sprzyja swobodnemu i „bardziej powszechnemu” łączeniu ze sobą „obrazów, odczuć, idei, wspomnień", a to, jak komentuje Wojciech Owczarski, dowodzi „kreatywności” snów i ich „pokrewieństwa ze sztuką" . Przy czym Hartmannowi zależy na akcentowaniu nie różnic, lecz płynnych przepływów między poszczególnymi stanami funkcjonowania umysłu, z których i śnienie, i skoncentrowane myślenie (właściwe zarówno dla studenta podczas

2 W. Owczarski Sennik polski: literatura, wyobraźnia i pamięć, słowo/obraz terytoria, Gdańsk 2014, S. 20-40.

3 E. Hartmann The nature and functions of dreaming, Oxford University Press, Oxford 2010, s. 31. Cytat podaję za przekładem W. Owczarskiego, zob. tegoż Sennik polski, s. 21.

4 E. Hartmann The nature and functions of dreaming, s. 31, przeł. W. Owczarski Sennik polski, s. 21.

5 W. Owczarski Sennik polski, s. 21. 
egzaminu, jak i piłkarza podchodzącego do rzutu karnego) stanowią tylko pewne ekstrema, które można by umieścić odpowiednio na „prawym” i „lewym" krańcu metaforycznego kontinuum.

Implikowane przez koncepcję amerykańskiego badacza zacieranie sztywnej opozycji między myśleniem analitycznym a kreacją artystyczną oczywiście nie jest niczym nowym. We „współczesnej teorii śnienia” słychać echa prowadzonych od kilkudziesięciu lat badań kognitywistycznych i neurosemiotycznych ${ }^{6}$, których antycypacje można by zresztą znaleźć już w inspirowanych filozofią Henriego Bergsona dyskusjach nad płynną granicą między "intuicją a intelektem"7 i „sztuką a nauką" z pierwszych dekad XX wieku. Teoria psychiki jako kontinuum była Hartmannowi potrzebna zwłaszcza do tego, by sfunkcjonalizować czynność śnienia. W jego koncepcji sen jest bowiem integralną częścią życia psychicznego - nie opozycyjną, lecz komplementarną względem myślenia na jawie; odpowiedzialną za włączanie do psychiki nowego "materiału” , często będącego konsekwencją doznanej traumy. Jest to możliwe dzięki właściwej dla śnienia „hiper-łączliwości”10 elementów z różnych sfer ludzkiego umysłu. Co istotne, elementy te nie są łączone przypadkowo, gdyż ogniskuje je konkretna emocja, która wywołuje i generuje obrazy oraz fabuły senne ${ }^{11}$. Im bardziej wyraziste sny, tym prawdopodobnie silniejsza emocja legła u ich podstaw.

Zwrócenie uwagi na niedocenione znaczenie snu - przez wskazanie na jego ważną funkcję w życiu psychicznym - również nie czyni z Hartmanna prekursora. Nie trzeba tu przywoływać dokonań Freudowskiej i Jungowskiej psychoanalizy - po pierwsze, dobrze znanych, po drugie, nie zawsze łatwych do pogodzenia z ustaleniami współczesnych psychiatrów i neurologów. Warto natomiast, choćby na marginesie, przypomnieć o trafnych intuicjach

6 J. Bruner O poznawaniu. Szkice na lewą rękę, przeł. E. Krasińska, PIW, Warszawa 1971; W. Iwanow Neurosemiotyka mowy ustnej a funkcjonalna asymetria mózgu, przeł. D. Ulicka, „Teksty Drugie” $2011 \mathrm{nr} 1 / 2$.

7 R. Ingarden Intuicja i intelekt u Henryka Bergsona. Przedstawienie teorii i próba krytyki, przeł. M. Turowicz, w: tegożZ badań nad filozofią współczesną, PWN, Warszawa 1963 (pierwodruk niemiecki: 1922).

8 O. Ortwin O prawdę w sztuce, „Nasz Kraj” (Lwów) 1909 z. 12-13; B. Leśmian Z rozmyślań o Bergsonie, w: tegoż Szkice literackie, oprac. ). Trznadel, PWN, Warszawa 1959 (pierwodruk: 1910). 
wyrażonych u progu lat 20. przez Leona Chwistka, łączącego role malarza, filozofa i matematyka. Jego teoria wielości rzeczywistości oparta była bowiem na podobnych przekonaniach względem snu, które obecnie żywi i udowadnia Hartmann, a które legły u podstaw również niniejszego wywodu. Odróżniając od siebie rzeczywistość wrażeń zmysłowych od rzeczywistości wyobrażeń (snów oraz marzeń) - istniejących, podobnie jak rzeczywistość fizykalna i rzeczywistość rzeczy, równolegle i niezależnie od siebie - Chwistek przywołał popularny przesąd, że wrażenia są bardziej realne od wyobrażeń, by natychmiast stwierdzić, iż „wizja (sen) nie jest zasadniczo niższa od jawy, gdyż wykazywać może nie tylko większą trwałość, ale i większą konsekwencję niż jawa [... ]"12.

Jeśli zatem na wstępie niniejszej analizy powołuję się na „współczesną teorię śnienia", a nie na inne, prekursorskie koncepcje oparte na fundamencie podobnych przekonań, robię to z racji wyjątkowej, moim zdaniem, operatywności Hartmannowskiej metafory psychiki jako kontinuum. Przyjmijmy bowiem, że twórczość Kąckiej stanowi takie kontinuum, na którego „lewym” krańcu znajduje się monografia o Brzozowskim, na "prawym” zaś - książka po drugiej stronie siebie. W konsekwencji przyjęcia tego założenia trzeba będzie uznać, że twórczość naukowa Kąckiej nie jest odseparowana jakąś niewidzialną granicą od jej twórczości literackiej, jej utwory literackie ani zatem nie powstawały „na boku”13 działalności naukowej, ani nie były formą ludycznej „zabawy literackiej”14 podejmowanej w przerwach od pracy akademickiej. Przeciwnie - uzupełniały się z nią.

L. Chwistek Wielość rzeczywistości, w: tegoż Pisma filozoficzne i logiczne, wybór.i red. K. Pasenkiewicz, PWN, Warszawa 1961, s. 64 (pierwodruk: 1921). Zob. dalszą część argumentacji: „Częste sprzeczności dostarczane przez marzenia są pozorne i płyną ze stosowania bezkrytycznego zasad jawy od obcego jej zakresu wizji. Tak np. nie możemy się zgodzić, że osoba, która umarła na jawie, jest tą samą osobą, którą spotykamy we śnie, jedynie z tego powodu, że przywykliśmy uważać tę osobę już to jako element świata rzeczy, już to jako zbiór wrażeń wzrokowych. Zgódźmy się jednak uznać wyobrażenia za prawdziwą rzeczywistość, dołączając do nich wrażenia zmysłowe jako mało ważną podgrupę - trudności znikną natychmiast" (tamże, s. 64). Uwagi Chwistka na temat roli i znaczenia snu w życiu człowieka wydają się dzisiaj zaskakująco aktualne, choć oczywiście nie wolno zapominać, że uczony wygłaszał je jedynie przy okazji włączania się do filozoficznego sporu między idealistami a realistami, inspirując się zresztą zacytowaną przezeń myślą Blaise'a Pascala, że „gdybyśmy śnili co noc o tej samej rzeczy, działałaby na nas może w tym samym stopniu, jak przedmioty, które widzimy codziennie" (tamże, s. 104).

13 A. Nawarecki Na boku, w: Na boku: pisarze teoretykami literatury?... (szkice), red. J. Olejniczak, M. Bogdanowska, Wydawnictwo Agencja Artystyczna Para, Katowice 2007. 
Chcę przy tym podkreślić, że przypadek Kąckiej jest tak interesujący nie dlatego, że autorka jednocześnie tworzy literaturę i publikuje rozprawy naukowe (w naszym środowisku jest to akurat przypadłość raczej powszechna), lecz z tej racji, że jest literaturoznawczynią, która zapisuje swoje sny. W snach wizualizowane są bowiem emocje, także te związane z pisaniem dysertacji (dość powiedzieć, że w senniku Kąckiej kilkukrotnie pojawia się sam Brzozowski). Kładę na to silny nacisk, ponieważ Lektura jako spotkanie stanowi rzetelną monografię historycznoliteracką, a nie eksperymentalny esej jawnie eksponujący podmiotowość piszącej. Toteż można przyjąć założenie, że sny przeżywane po drugiej stronie siebie dopowiadają to, co nie zmieściło się w konwencji w gruncie rzeczy tradycyjnego wywodu akademickiego. Mówiąc wprost, zdradzają one zaangażowanie i kulturowe usytuowanie autorki przygotowywanej rozprawy, a tym samym zacierają implikowany przez strukturę jej wywodu podmiotowo-przedmiotowy dystans.

I między innymi dlatego warte są analizy.

\section{Budzenie myśli}

Narratorka Kąckiej („eliza”) zapisuje sny według schematu: najpierw krótko informuje o okolicznościach zaśnięcia, potem opowiada treść snu, na końcu zaś pisze, w którym momencie się obudziła (czasem też - w jakim stanie emocjonalnym). Opatrzone datami zapisy rozpoczynają się rozmaicie: „śniło mi się, że” (11),, dziwny sen” (43), ,,sen” (66). Zwraca uwagę to, że „eliza” często śni nie podczas długich nocy, lecz „po kąpieli w jeziorze”, na ławce przed domem, nierzadko ucina sobie również „drzemki-pięciominutówki na kompie” w „B[ibliotece] N[arodowej]” albo „drzemki przy otwartym kompie”. Dwa ostatnie cytaty pozwalają z dużą dozą prawdopodobieństwa zrekonstruować swoistą sytuację liryczną. Oto narratorka zasypia, by choć na chwilę odpocząć od kreślenia ołówkiem po książkach i od śledzenia kursora w edytorze tekstowym. Wszak spanie - jak przekonywał Bert O. States, autor The Rhetoric of Dreams (1988) - jest konieczne, by „przetworzyć niewyobrażalną ilość informacji pochłanianych w ciągu dnia. Organizm musi odciąć dopływ wszystkich napływających danych, by mózg mógł przetworzyć i uporządkować całodzienny przyrost doświadczeń zmysłowych w swoich bankach pamięci"15.

Zapisy Kąckiej mogłyby stanowić obrazową ilustrację hipotezy amerykańskiego badacza. Podjęta przez narratorkę jej prozy praca intelektualna,

B. States The rhetoric of dreams, Cornell University Press, New York 1988, s. 16-17. 
przytłaczająca umysł lekturą niekończących się studiów składających się na stan badań, a także poziomem komplikacji własnych przemyśleń, bywa na krótki czas zawieszana i wówczas punkt ciężkości przesuwa się z „lewego” krańca kontinuum na koniec „prawy”. Treści psychiczne związane z problematyką monografii historycznoliterackiej opuszczają macierzysty kontekst, swobodnie łącząc się z innymi treściami umysłu „elizy”. Prowadzi to do generowania nierzadko groteskowych i komicznych fabuł sennych.

W pierwszym opisanym śnie narratorka cierpi na nałóg połykania torebek po herbacie, które zalegają w jej trzustce (co skądinąd jest dobrym przykładem typowej dla snu kontaminacji - wszak trzustka jako organ odpowiedzialny za produkcję enzymów trawiennych nie jest tu zupełnie od rzeczy). Ponieważ „eliza” czuła się coraz gorzej, postanowiła wybrać się do polecanego jej lekarza, którym okazał się „Stanisław Brzozowski”:

„[...] czy pani wie, kim ja jestem? ja się nie po to uczyłem, żeby czyścić panienki z herbatek. jakbyście nie łykały, to bym pojechał do Anglii i robił poważne operacje. a na tym zatyłczu da się tylko liptony z kretynek wyciągać". no ta, zaszył mnie i moje poczucie winy (10).

Wedle jednej z antropologicznych teorii snu, autentyczne postacie, które spotykamy po zaśnięciu, są połączeniem, po pierwsze, osób znanych nam z życia lub z opowieści, po drugie, zarówno naszych myśli i emocji związanych z tymi osobami, jak i ich myśli i emocji dotyczących nas, które my zinterioryzowaliśmy na jawie ${ }^{16}$. Toteż w trakcie snu ,ja" ulega rozczłonkowaniu - dzieli się na „role” („Brzozowskiego" i „elizy”), które biorą udział w swoistym spektaklu odgrywanym wewnątrz jaźni osoby śniącej. Dodajmy, że „role” te pozostają względem opisującej sen narratorki w takiej relacji, w jakiej znajduje się podmiot dramatyczny względem bohaterów (zgodnie bowiem ze znaną koncepcją tekstu dramatycznego nadrzędny podmiot jest odpowiedzialny za fabułę i wypowiedzi wszystkich postaci, ale nie za wypowiedź każdego bohatera z osobna $\left.{ }^{17}\right)$. Jeannette Marie Mageo - dowodząc, że sny kształtują ludzką tożsamość w nie mniejszym stopniu niż poczynania i myśli na jawie - twierdzi, iż po przebudzeniu człowiek projektuje obrazy innych ze swojego

16 J. Mageo Theorizing dreaming and the self, w: Dreaming and the self: new perspectives on subjectivity, identity, and emotion, ed. by J. Mageo, State University of New York Press, New York 2003, s. 10.

17 A. Ubersfeld Lire le théâtre III. Le dialogue de théâtre, Belin, Paris 1996, s. 11. 
snu na rzeczywiste znane mu osoby, by później osoby te ponownie wkroczyły do jego snów i reprezentowały jego własne emocje - i tak ad infinitum ${ }^{18}$. Wynika z tego niezbicie, że sny biorą ogromny udział w kształtowaniu naszego „ja”.

Z mojego punktu widzenia najistotniejsze jest to, w jaki sposób wzajemne oddziaływanie snu i jawy wpływało na ujęcie związanej z Brzozowskim, tytułowej problematyki monografii Kąckiej. Głównym tematem Lektury jako spotkania jest bowiem relacja Brzozowskiego z dziełem myślicieli kształtującym - w trudnym do przeszacowania stopniu - jego własne myślenie i osobowość: Cyprianem Norwidem, Giambattistą Vikiem oraz Johnem Henrym Newmanem. Na próbie opisania osobliwości tej relacji zasadzają się dwa rozdziały wstępne. Kącka otwiera wywód cytatem z dialogu Fryderyk Nietzsche, w którym padają słowa: „Mówimy o wpływie wielkich twórców, jakby to była istotnie jakaś siła całkowicie zewnętrzna, wytwarzająca w nas coś zupełnie nowego. Czy może dać nam największe dzieło coś, czego nie mielibyśmy w sobie?"19. Badaczka przekonuje, że tę argumentację podzielał sam Brzozowski, który:

czytał nie po to, by dojść (cokolwiek miałoby to znaczyć) prawdy tekstu i na jej ujawnieniu poprzestać. Przeciwnie: czytał, by to, co poddawane lekturze, wyemancypowało się w podmiotowość, którą następnie uwewnętrznia się i wzywa do dysputy, wyzywa na pojedynek. Czytał zatem, by katalizować własny rozwój, by budować siebie-nowego. ${ }^{20}$

Nie jest to banalne twierdzenie o budowaniu tożsamości w dialogu z innymi. Zauważmy, że badaczka rekonstruuje mechanizm analogiczny do kształtowania „ja” w procesie snu. Oto bowiem Brzozowski miałby interioryzować swoje emocje odczuwane względem lekturowych partnerów, czyniąc Norwida, Vica i Newmana korelatami swojej świadomości, a potem prowadziłby z nimi intelektualny dialog, którego wynik, kształtujący jego postrzeganie rzeczywistości, byłby następnie rzutowany na pisane przez Brzozowskiego eseje im poświęcone. To, że swoich partnerów autor znał tylko z lektur, nie jest bez znaczenia. Dzięki niemu bowiem na dobitności zyskuje fakt, że

18 J. Mageo Theorizing dreaming and the self, s. 10.

19 S. Brzozowski Kultura i życie. Zagadnienia sztuki i twórczości. W walce o światopogląd, wstęp A. Walicki, oprac. K. Podgórecka, PIW, Wydawnictwo Literackie, Warszawa-Kraków 1973, s. $634-635$. 
intelektualiści owi funkcjonują w jego tekstach wyłącznie jako kontaminacje jego myśli i emocji. Są, podobnie jak osoby spotykane we śnie, treściami jego życia psychicznego.

Nie wiem, czy Kącka świadomie korzystała z tej analogii, w jej monografii znajduję natomiast wskazujące na to poszlaki retoryczne. Otóż charakteryzując praktykę czytelniczą Brzozowskiego, badaczka jako znamienną dla bohatera swojej rozprawy uznaje ścieżkę lekturową sprowadzającą się do „spotkania z myślą własną":

Na takiej właśnie zasadzie podobne umysłowości wyłaniają swoich bohaterów. A ci z przedmiotu dociekań stają się podmiotowym źródłem inspiracji, zinternalizowanym agensem, który nareszcie oferuje coś trwałego i niezmiennego - myśl, której mogę zaufać, bo przebywała już we mnie w stadium u ś p i e n i a. Myśl, dodajmy, pozytywną, która - o b u d z o n a - staje się trwałym składnikiem naszego ja [podkr. moje - A.H.]. ${ }^{21}$

W tym fragmencie rozważań uderzające są dwie rzeczy. Po pierwsze, przypadkiem lub nie Kącka posługuje się metaforyką snu i przebudzenia - i to właśnie w kontekście problemu konstruowania tożsamości, w zgodzie z ustaleniami współczesnych antropologów snu. Po drugie, korzystając z możliwości, jaką oferuje polszczyzna, spostrzeżenie to - nienaruszające rygorów dyskursu akademickiego - wyraża w pierwszej osobie liczby pojedynczej, co w innej partii wywodu zapewne nie zwróciłoby uwagi czytelnika, tu jednak zachęca do dwojakiej interpretacji, zarówno jako (przedmiotowego) tłumaczenia praktyki lekturowej Brzozowskiego, jak (podmiotowego) wyznania samej badaczki.

W samej rozprawie prywatny stosunek autorki do problematyki monografii o Brzozowskim nie ujawnia się jednak ostentacyjnie. Oświetla go dopiero kontekst zapisanych gdzie indziej snów. Hipotezę o istnieniu tego osobistego stosunku opieram na spostrzeżeniu, że w książce po drugiej stronie siebie „eliza” jako własne traktuje te same problemy, które w Lekturze jako spotkaniu Kącka omawia w odniesieniu do dzieła i myśli Brzozowskiego.

By tego dowieść, zwrócę teraz uwagę na jedną z konstatacji Kąckiej na temat Brzozowskiego związaną z (na pozór tylko osobliwym) rysem osobowości tego pisarza i filozofa. Wychodząc od stwierdzenia, że autor Idei zmagał się z uwewnętrznionym przez antypozytywistów przekonaniem, iż „podmiot

Tamże, s. 12-13. 
nie tyle staje się, co zmienia, jedno zyskując, drugie tracąc"22, badaczka formułuje następującą tezę: „Postawa człowieka myśli, który dąży, uległa niepostrzeżenie przemianie w nieco komiczną postawę kogoś, kto lepiej lub gorzej nadą̇a"23. Rzeczywiście trudno o trafniejsze opisanie nawyku intelektualnego Brzozowskiego - ogromnego, lecz istotnie dość nieuporządkowanego w swej namiętności poznania erudyty, nałogowo czytającego i nieustannie zdającego relację ze swych „kompulsywnych szturmów na kilka naraz twierdz kultury europejskiej"24; myśliciela stale rekonstruującego architektonikę ogromnego, budowanego w swym umyśle gmachu, złożonego z nazwisk i idei wielkich pisarzy i filozofów.

Jasne jest, że w czynność nadążania immanentnie wpisana jest obawa pozostania w tyle, gdyby bowiem człowiek był tej obawy pozbawiony, nie pochłaniałby kolejnych lektur z taką kompulsywnością. Wydaje się, że podobny lęk przed nienadążeniem trapi również narratorkę książki po drugiej stronie siebie. Przyjrzyjmy się snowi, w którym „eliza” spotyka „Brzozowskiego” w miejscowości letniskowej na Mazurach:

stoję sobie na pomoście zawstydzona i kombinuję, czy mu powiedzieć, że można zdjąć frak w taki gorąc. „o co chodzi, pani elizo?” - pyta się Brzozo, również zawstydzony (a pyta się głosem Michnikowskiego, co brzmi poniekąd dziwnie). tak, zawstydzam się bardziej i szukam innego pytania. „co pan pisze?” - „pamiętnik”. tak, Brzozowski trzyma notes na kłódkę w różowej okładce, z tych lukrowanie księżniczkowych. zerka na mnie wrednie: „nikt takiego nie ma, nie dam”. mówię: „też taki miałam, ale wyrosłam”. Brzozo: „a nie masz, bo mi Nałkowska wpisała «Na górze róże»". a ja myślę wtedy, że nie znam żadnej Nałkowskiej. a potem, że Irzykowski ma rację: Brzozowski jest nieznośny (14).

Czytelnik styka się z sytuacją zapewne dobrze mu znaną: śniące, ,ja” nie wie tego, co doskonale wie „ja” na jawie. Zauważmy, że choć „eliza” nie zna Nałkowskiej, zna ją przecież „Brzozowski”, będący w równym stopniu wytworem psychiki Kąckiej. W tym sennym spektaklu została mu bowiem przydzielona rola „nieznośnego" rówieśnika, popisującego się znajomościami z ludźmi, o których jego

\footnotetext{
22 Tamże, s. 9.

23 Tamże, s. 9-10.

24 Tamże, s. 7.
} 
rozmówczyni nie ma pojęcia. Jeśli więc przyjmiemy, że fabuły senne są obrazami autentycznych myśli i emocji, trzeba będzie przystać i na to, że tym, co wizualizuje mazurska konwersacja, jest lęk „elizy” przed ujawnieniem jej niewiedzy.

Snów obrazujących podobne myśli i emocje jest w książce Kąckiej znacznie więcej. W lipcu 2015 roku narratorce przyśniło się, że wszystko, co robi w życiu dorosłym, „trafiło ponownie do ławki”. Najpierw nie radzi sobie na lekcji „Pisanie recenzji” - najnowszy tomik „Białoszewskiego” okazuje się zbyt dużym wyzwaniem, nauczycielka ją karci i zleca jej do domu zrecenzowanie książki „łatwiejszego” „Franaszka”. Później oblewa „Pisanie doktoratu”, by na koniec, w rozmowie z „Ważykiem”, palnąć gafę podczas „Prowadzenia spotkań kulturalnych" (28-29). W innym śnie z jeziora wyłania się miasto, które proponuje narratorce, by się z nim „zabrała”., «[A]le dlaczego ja?»” - „«bo na powierzchni nie dajesz rady»" (31).Znamienny jest także sen, w którym wszyscy ludzie podjęli się nauki nowego języka. Ma on wkrótce wyprzeć inne języki. Mama upomina narratorkę, by i ona ruszyła do pracy, nowego języka uczą się zresztą wszyscy w bibliotece, nawet „prezydent robi postępy” („a ja nie mogę zacząć"). Czas mija dopóty, dopóki nie zmaterializuje się najgorszy lęk: nowy język ostatecznie wyparł polszczyznę, a "eliza” "straciła mowę” i nie potrafiła nawet zapisać własnego imienia (47).

Nie jest to pełna lista snów wizualizujących, jak się zdaje, podobne lęki narratorki. Z obawą przed nienadążeniem łączy się również poczucie nieprzygotowania. Łatwo zauważyć, że sennymi wyobrażeniami towarzyszącymi temu poczuciu są na przykład sytuacje, gdy narratorka przypłaca wygłoszenie nieudanego referatu ustrzeleniem ze stojącej na widowni armaty (11), albo kiedy „Dycki i HGW” surowo oceniają jej opieszałość w przebieraniu się podczas egzaminu przypominającego obronę doktoratu (27), a także wówczas gdy „eliza” orientuje się, że jest nieubrana, a części jej garderoby zalegają w różnych częściach Warszawy.

Konsekwentnie piszę o snach narratorki „elizy”, a nie samej Kąckiej, zależy mi bowiem na podkreśleniu, że nie o psychologizację twórczości (zwłaszcza naukowej) tutaj idzie. Chodzi natomiast o wskazanie problematyki, która jest tematyzowana, w odmienny sposób, zarówno w jej książce literackiej, jak i monografii naukowej. Ujęcia te uzupełniają się ze sobą, dzięki czemu po lekturze książki po drugiej stronie siebie możliwe staje się uchwycenie tych aspektów monografii Lektura jako spotkanie, które w innym razie mogłyby zostać przeoczone.

Z tego względu skłaniam się ku spostrzeżeniu Wojciecha Owczarskiego, który - przywołując określenie Georges’a Pouleta - stwierdził, że zapisy 
snów w polskiej literaturze warto potraktować jako „punkt wyjścia” („prawdę pierwszą" o danym autorze, „zalążek myślenia o sobie i myślenia w ogóle”) do analizy twórczości pojmowanej jako pole przejawów aktywności określonego podmiotu ${ }^{25}$. Gdy, powiada Owczarski, przedmiotem naszego zainteresowania jest tożsamość pisarek i pisarzy, wówczas, jeśli to możliwe, należy rozpocząć od przyjrzenia się zapisanym przez nich snom, katalizującym istotne emocje oraz myśli ${ }^{26}$.

W moim przekonaniu lektura snów zapisanych w książce po drugiej stronie siebie stanowi taki właśnie dogodny „punkt wyjścia” do uchwycenia centralnej problematyki twórczości Kąckiej - niedzielonej na naukową i nienaukową. Tym samym badanie jej snów staje się możliwym "punktem wyjścia” do ujmowania koncepcji literaturoznawczej w duchu biograficznym (kulturowym), przekonującą propozycją alternatywną wobec uprawiania historii sztucznie wypreparowanych, abstrakcyjnych idei.

\section{Dziennik snów a autobiografia}

W świetle tego, co powiedziane wyżej, można by podmiot „całej” twórczości Kąckiej określić mianem wielojęzycznego. Przywołuję ten Bachtinowski termin nie bez powodu. Na związek między antropologiczną teorią snu a ideą heteroglozji zwracała uwagę cytowana wcześniej Mageo, przekonując, że we śnie nasze „ja” zostaje rozdzielone na różne, współbrzmiące ze sobą "głosy", czyli postacie ze snu ${ }^{27}$. Analogicznie do snu relacja ta przedstawia się w odniesieniu do twórczości, której podmiot wypowiada się w odmiennych gatunkach mowy (rozprawie akademickiej, prozie poetyckiej), stając się przez to podmiotem wielogłosowym, zachowującym jednak indywidualność.

Tak rozumiana podmiotowość była i jest, zdaniem Danuty Ulickiej, alternatywą dla „modernistycznej koncepcji autora”: „monumentalnie jednolitego, zwartego i silnego, niezachwianego w swych poglądach, władającego idiomem wyrazistego stylu reprezentującego «integralną osobowość», którego właściwą formą wypowiedzi jest monolog"28. Odwróćmy tę definicję,

\footnotetext{
25 W. Owczarski Sennik polski, s. 33.

26 Tamże.

27 J. Mageo Theorizing dreaming and the self, s. 9.

28 D. Ulicka Słowa i ludzie - 10 szkiców z antropologii filologicznej, Wydawnictwo IBL, Warszawa 2013, S. 313 .
} 
a uzyskamy opis podmiotu niejednolitego, słabego, posługującego się różnymi stylami, które stanowią odzwierciedlenia procesualnego, podatnego na ciągłe rekonstytucje kształtowania jego wiecznie niefinalnej tożsamości. Podmiotu wewnętrznie zdialogizowanego i stale - w autorefleksyjnym geście - podważającego własne przekonania.

Celowo wyostrzam opozycję między modernistyczną a Bachtinowską koncepcją autora, by zwrócić uwagę na jeszcze jeden istotny aspekt utworu Kąckiej. Na skrzydełku okładki możemy bowiem przeczytać - a pośrednio sugeruje to sam tytuł - że książka po drugiej stronie siebie jest „pierwszą w Polsce senną autobiografią". Cytowane sformułowanie pojmuję jako zamierzony oksymoron. Wiadomo wszak, że zarówno gatunek autobiografii, jak i samo przedsięwzięcie ogłoszenia wyznań drukiem wyrastały z dziedzictwa oświeceniowego racjonalizmu. Toteż klasyczni intymiści z rzadka traktowali sny z powaga, gdyż pozostawały one poza kontrolą racjonalnego, samoprzejrzystego ego cogito. Obrazowo wypowiedziała się na ten temat Hélène Cixous, pisząc, że podczas snu odrywamy się od konstruowania "ja” i wyruszamy w podróż, w jaką udawały się córki króla z jednej baśni braci Grimm, wymykające się do lasu tajnym wyjściem ukrytym pod ich łóżkiem i tańczące przez całą noc. W tym sensie, puentuje filozofka, śnienie jest równoznaczne z łamaniem zakazu i przekraczaniem własnego „ja”29.

Złożony z krótkich, nie zawsze łatwych do zracjonalizowania onirycznych fabuł utwór Kąckiej jest raportem z takich potajemnych wycieczek do lasu. Jego tytuł stanowi oczywiście aluzję do drugiej części przygód Alicji Lewisa Carrolla (Po drugiej stronie lustra). Przeglądanie się w zwierciadle, co wiadomo i bez znajomości teorii Jacques'a Lacana, prowadzi do tworzenia wyobrażenia na swój temat. Względem tego właśnie zamierzenia, właściwego autobiografii, Kącka wskazuje podejście alternatywne. Podobnie jak „naiwnej bajeczce z nieprawdziwego zdarzenia", powołanej do życia w Elizjach, autorka wyznaczyła swoim snom rolę „miłego cienia poważnych narracji, spokojnej i niepozornej niemotki na zapleczu mocnych fabuł" ${ }^{\text {"30 }}$. Jej utwór równie dobrze mógłby więc nosić tytuł „po drugiej stronie autobiografii”.

Jest tak również z tej racji, że - w przeciwieństwie do opartej na fundamencie Kartezjańskiej koncepcji podmiotu autobiografii - stanowi on dobitne świadectwo nierozumienia samej siebie. „Dziwne sny”, jak niektóre

29 H. Cixous Three Steps on the Ladder of Writing, w: The Helene Cixous Reader, ed. by S. Sellers, Routledge, London-New York 2000, s. 201-203. 
z nich określa sama narratorka, pozbawione początku i urwane w trakcie, nie są przez nią obszerniej komentowane ani tym bardziej wyjaśniane, a jedynie relacjonowane w tonie świeżo zasłyszanej, gorącej anegdoty. Jak wiadomo, nowo poznane anegdoty opowiada się nie tylko dla nich samych, lecz także by poznać reakcję drugiej osoby na ich temat $i$, ewentualnie, na jej podstawie wyrobić sobie stanowisko własne. Można odnieść wrażenie, że również Kącka opowiada swej czytelniczce sny w takim tonie, jakby liczyła, że może choć ona coś zrozumie. Być może o odrębności jej utworu względem innych zapisów snów w polskiej literaturze decyduje to, że narratorka przedstawia senne fabuły tak, jakby stanowiły one zagadki dla niej samej. Po drugiej stronie siebie byłoby zatem świadectwem tyleż nierozumienia samej siebie, co nienadążania za sobą.

Tak ujętą książkę Kąckiej z całą pewnością można zaliczyć w poczet dziedzictwa "kultury siebie" wiążącej się z koncepcją podmiotu relacyjnego i nieprzejrzystego dla samego siebie. Jest to koncepcja alternatywna względem

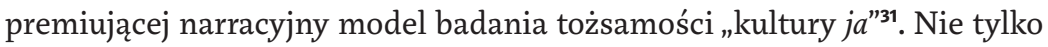
dlatego, że zaimek „siebie” stanowi część tytułu utworu Kąckiej. Do dziennika jej snów bardzo dobrze przystają słowa Romy Sendyki, którymi badaczka ta opisywała typ podmiotu charakterystyczny dla „kultury siebie”. Zamiast dokonywania wysiłku ,autoeksplikacji i dyskursywizacji swojego doświadczenia"32, podmiot ów rozpoznaje „odzwierciedlenia siebie" przez odpowiadanie na pytania, czym są dla niego przedmioty (kultury), procesy społeczne i inne jaźnie ${ }^{33}$. Sendyka zwraca uwagę, że jest on typowy dla eseistyki - czytanej,jak za Henrykiem Berezą zauważył Jakub Nowacki, „mniej dla tego, o czym jest mowa, a bardziej dla tego, który mówi”. Wprawdzie autor rzadko wypowiada się wprost, tworzy jednak pewną „narrację o sobie”34.

Punktem odniesienia dla koncepcji podmiotu eseistycznego badaczka uczyniła eseistykę Brzozowskiego - spotykającego w cudzych pismach „myśl własną". Była już mowa o analogii między strategią lekturowo-tożsamościotwórczą autora Idei a antropologiczną teorią snu. Nie powinno dziwić, że strukturalne podobieństwo istnieje również między podmiotem eseistyki

31 R. Sendyka Od kultury "ja” do kultury "siebie”. O zwrotnych formach w projektach tożsamościowych, Universitas, Kraków 2015.

Tamże, s. 15 .

34 J. Nowacki Tadeusz Komendant, tak jak go widzę, "Mały Format” 2017 nr 12, http://malyformat. com/2017/12/tadeusz-komendant-go-widze/ (0.09.2019). 
Brzozowskiego opisywanym przez Sendykę a sytuacją „elizy”, która, znalazłszy się po drugiej stronie siebie, z każdą kolejną drzemką rozpoznaje nowe „odzwierciedlenie siebie” (co czyni jej sny „narracjami o sobie”). Ta zbieżność wynika oczywiście z tego, że i Kącka, i Sendyka są uważnymi czytelniczkami Brzozowskiego, inspirującymi się tymi samymi rozważaniami o tożsamości i dialogu z innymi.

Cytowane określenie Sendyki warto także odnieść do głównej problematyki niniejszego artykułu. Per analogiam można bowiem powiedzieć, że podmiot „wielojęzycznej” twórczości Kąckiej rozpoznaje rozmaite „odzwierciedlenia siebie" w poszczególnych gatunkach mowy. Mam tu na myśli zarówno jej teksty literackie, szkice i recenzje krytycznoliterackie, jak i rozprawy naukowe. Wbrew pozorom, które stwarza podmiotowo-przedmiotowy dystans, Lekture jako spotkanie zasadnie można czytać jako niebezpośrednią narrację autorki o „sobie”, ciekawą nie tylko ze względu na to, o czym mowa, lecz również z uwagi na tę, która mówi. Oczywiście oderwane od kontekstu jej pisarstwa nienaukowego, raczej tradycyjne formalnie studium nie implikowałyby takiego obrazu autorki. Czytając dobrze skonstruowany, zobiektywizowany tekst naukowy, łatwo zapomnieć, że stanowi on realizację jednego z wielu gatunków mowy, poprzez który wypowiada się jakiś podmiot. Ale spojrzymy na ten tekst inaczej, jeśli potraktujemy twórczość „wielojęzycznej” autorki jako kontinuum. Być może nie przywiedzie nas to do radykalnej konstatacji, że Kącka tworzy naukę nawet wtedy, gdy śpi (choć i za taką tezą można by obstawać), z całą pewnością pozwoli natomiast sformułować (oczywistą, mimo iż chyba nie w pełni oswojoną) myśl, że zarówno rozprawy naukowe Kąckiej, jak i jej literacki dziennik snów są zapisami nigdy nieukończonego tworzenia siebie. 


\section{Abstract}

\section{Artur Hellich}

UNIVERSITY OF WARSAW

Dreams and Science

Hellich examines the scholarly and literary work of Eliza Kącka (b. 1982) in the context of dream studies. Drawing on Ernest Hartmann's theory of the dream as part of a continuum Hellich tackles Kącka's output as a whole and points out interferences between two texts written at the same time, namely a literary historical monograph and a literary dream journal. Hellich suggests that Kącka's dream journal reveals an implicit or"private: dimension of her scholarly work - a sort of "narrative about herself". In the second part of the article Hellich reads the dream journal in terms of Kącka playing with the genre of autobiography, as well as an attempt to describe the subject of Kącka's writing understood as a multilingual whole.

\section{Keywords}

contemporary dream theory, science, subject, autobiography, dream journal, multilingualism 